\title{
A Study on Adoption Level of Recommended Cultivation Practices of Blackgram Growers in North Eastern Karnataka, India
}

\author{
B. Ashokkumar", J. Tulasiram, G.N. Maraddi and Basavaraj Hulagur \\ Department of Agricultural Extension Education, College of Agriculture, Raichur University \\ of Agricultural Sciences, Raichur - 584 104, Karnataka, India \\ *Corresponding author
}

\section{A B S T R A C T}

\begin{tabular}{|l|}
\hline K e y w o r d s \\
Adoption, Blackgram, \\
Growers, \\
Recommended \\
cultivation, North \\
Eastern Karnataka
\end{tabular}

\section{Introduction}

Pulse crops play an important role in Indian agriculture. Besides being rich in protein, pulses are the main sources of essential amino acids for predominantly vegetarian population of India. They contain 22-24 per cent of protein, which is almost twice the protein in wheat and thrice as that of rice. India is the leading country in pulse area and contributes 25 and 27 per cent of the world's pulse production and consumption, respectively. Major pulses grown in India include chickpea, pigeonpea, lentil, blackgram, mungbean, lablabbean, mothbean, horsegram, pea,

\begin{abstract}
India is the world's largest producer as well as consumer of blackgram. It produces about 1.5 to 1.9 million tonnes of blackgram annually from about 3.5 million hectares area, with an average productivity of $500 \mathrm{~kg}$ per hectares. In Karnataka, blackgram occupies an area of 1.26 lakh ha with the production of 0.64 lakh tones and productivity of $507 \mathrm{~kg} / \mathrm{ha}$. The study was conducted in Bidar and Kalaburagi districts of North Eastern Karnataka during the year 2014-15 to know the adoption level of recommended cultivation practices of growers. One taluka was selected from each district and three villages from were selected randomly making a total sample size of 120 . The ex post-facto research design was used for the study. The results of the study revealed that, overall adoption of recommended cultivation practices of blackgram, majority $(45.00 \%)$ of respondents had medium level adoption category followed by 29.17 per cent and 25.83 per cent of the respondents in low and high level adoption categories, respectively.
\end{abstract}

grasspea or khesari, cowpea, and broadbean or fababean. Among the various pulses, blackgram or urdbean [Vigna mungo (L.) Hepper] belonging to the tribe phaseolea of legume family is of immense importance as it is rich source of phosphoric acid. Blackgram is a rich source of protein and it gives 340 calories per $100 \mathrm{~g}$ dry weight. This crop contains 20-25 per cent i.e double the amount of proteins compared to cereals. Urd is said to have originated in India where it is most widely grown grain legume. It is known as poor man's meat and constitutes a major source of dietary protein of the large section of vegetarian population of the world.India is the 
world's largest producer as well as consumer of blackgram. It produces about 1.5 to 1.9 million tonnes of blackgram annually from about 3.5 million hectares area, with an average productivity of $500 \mathrm{~kg}$ per hectares. In Karnataka, blackgram occupies an area of 1.26 lakh ha with the production of 0.64 lakh tones and productivity of $507 \mathrm{~kg} / \mathrm{ha}$. The major urdbean growing states of the country are Maharashtra, Andhra Pradesh, Uttar Pradesh, Madhya Pradesh, Tamil Nadu and Karanataka. In Karnataka, major blackgram growing districts are Bidar, Kalaburgi, Raichur, Yadgir, Bijapur, Baglakot, Dharwad, Bellari, Koppal and Belgaum districts of Northern Karnataka (Anon., 2012). The yield and area expansion of blackgram and greengram are widely limited by inadequate availability of improved seed and knowledge of optimum cultivation practices, limited policy and marketing support and inadequate storage and processing facilities. The primary reason for the uncertainty of yield harvested at the end of the crop season is aberrant weather conditions, which cause extremes of soil water stress, ranging from drought to excessive soil moisture and high atmospheric humidity. The adoption of improved varieties of pulses should be emphasised and transfer of technology in relation to blackgram and other pulses should be strengthened in farmer participatory mode with active involvement of multidisciplinary team of scientists in order to increase the productivity of pulses. Creation of informal seed village system is required, where farmer to farmer seed production and distribution chain will ensure easy availability of quality seed. Improvement in agriculture is possible with the adoption of new and modern farming agro-techniques. New agriculture techniques are disseminating through extension methods. Extension methods like demonstration, training programmers, field days, extension group meeting, agricultural exhibition, krishimela, educational tour and field visit etc., are some of the major weapons for introducing the findings of modern research in agricultural practices to increase agricultural production in particular on sustainable income of the rural masses in general.

\section{Materials and Methods}

To know the adoption level of blackgram growers about recommended cultivation practices in North Eastern Karnataka, the research study was conducted in Bidar and Kalaburagi districts of North Eastern Karnataka during the year 2014-15. These districts were purposively selected as these ranks first and second in area and production of blackgram. Among five talukas of Bidar district, Bhalkitaluka had the maximum area under blackgram. Similarly, among seven talukas of Kalaburagi district Chincholitaluka had maximum area. Hence, Bhalkitaluka from Bidar district and Chincholitaluka from Kalaburagi district were purposively selected for the study area. Three villages were selected from each taluka. From each selected village, 20 blackgram growers were selected randomly. Thus, sample from each taluka was 60 , making a total sample size of 120 . The ex post-facto research design was used for the study. An interview schedule was developed and used to collect the information from blackgram growers. Personal interview technique was used for data collection. The data generated were analysed and presented by using mean, frequency and standard deviation

\section{Results and Discussion}

\section{Overall adoption of blackgram growers about recommended cultivation practices}

Overall adoption of recommended cultivation practices of blackgram by the selected respondents is presented in Table 1 and figure 1. The results revealed that, majority $(45.00$ $\%$ ) of respondents had medium level adoption 
category followed by 29.17 per cent and 25.83 per cent of the respondents in low and high level adoption categories, respectively. The reason might be that, majority of the farmers had high school level education, medium land holding, medium level achievement motivation, medium innovativeness and medium level management orientation.

Hence, all these factors might have influenced them to fall under medium adoption category. Further, as the land holding and income increases naturally and they prove towards economical returns. Good education level and farming experience might have increased their knowledge level and hence fell in medium adoption category so as to gain more income.The findings are in conformity with the findings of Venkataramalu (2003), Sunil Kumar (2004), Moulasab (2004), Tripathi et al., (2006), Upma et al., (2010) and Dwivedi et al., (2011).

Practise-wise adoption of blackgram growers about recommended cultivation practices

The adoption of any technology and recommended cultivation practices of blackgram in particular depends on various factors such as awareness about practices, extent of change agencies efforts, complexity of practices, timely availability of inputs, characteristics of farmers etc. However, it is true that all the recommended practices will not be adapted to some degree by all the members in a given social system. The findings with respect to adoption of blackgram cultivation practices by the respondents which are presented in the Table 2 and figure 2.

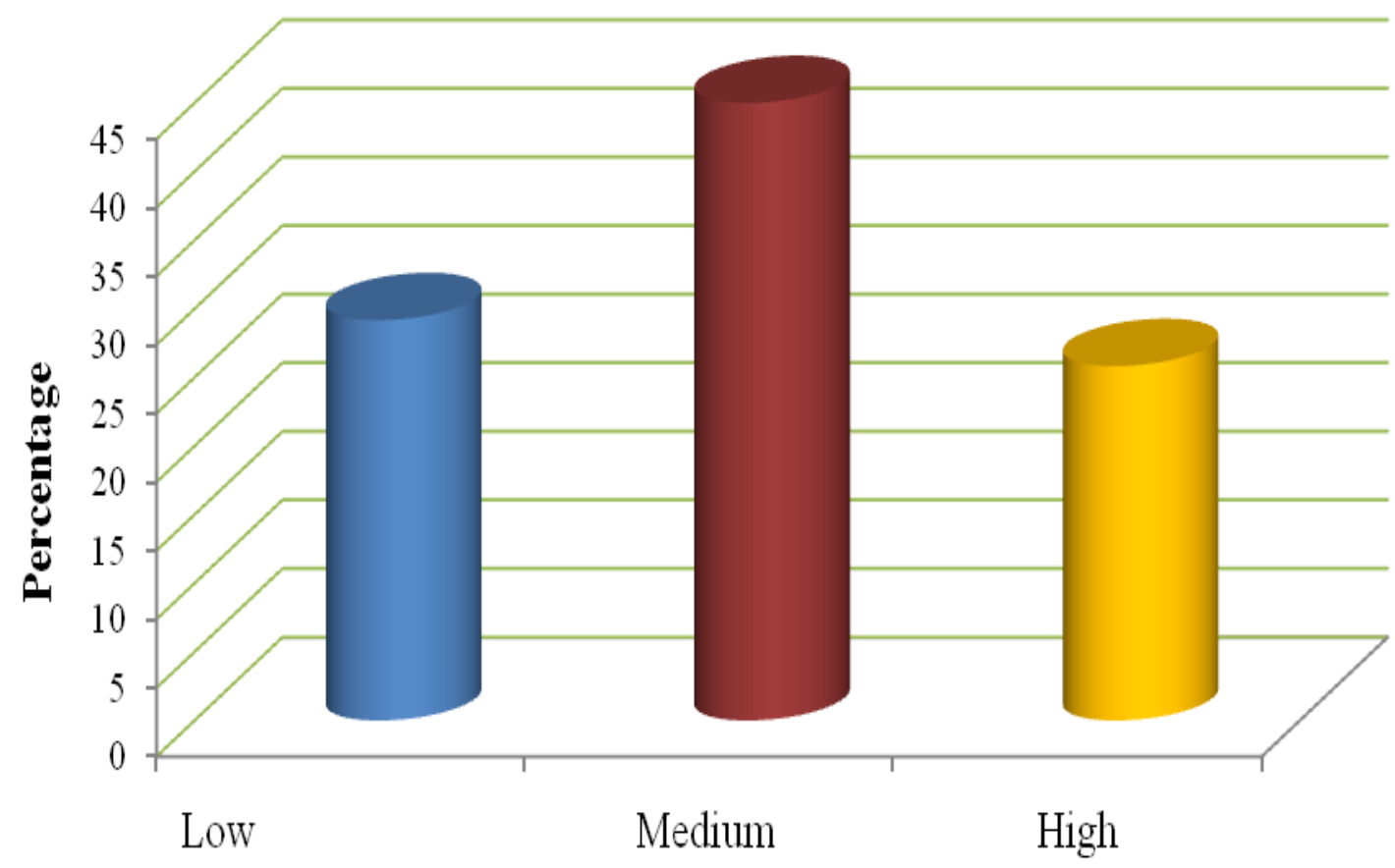

Fig. 1: Overall adoption of blackgram growers about recommended cultivation practices 


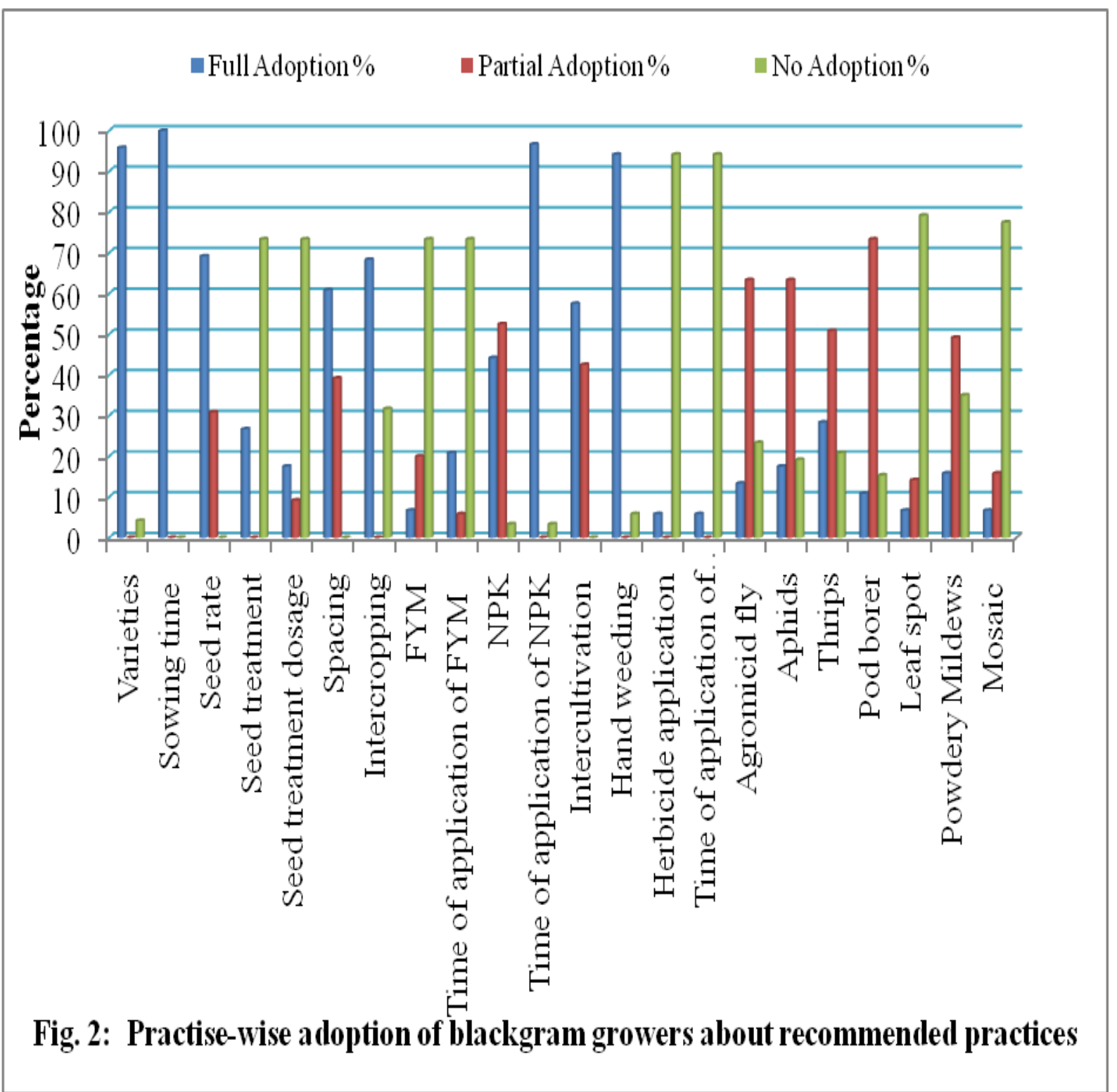

Table.1 Overall adoption of blackgram growers about recommended cultivation practices

$(n=120)$

\begin{tabular}{|c|c|c|c|}
\hline Sl. No. & Category & Frequency & Percentage \\
\hline 1 & Less than (mean $-0.425 * \mathrm{SD})$ & 34 & 29.17 \\
\hline 2 & Between $($ mean $\pm 0.425 * \mathrm{SD})$ & 54 & 45.00 \\
\hline 3 & More than $($ mean $+0.425 * \mathrm{SD})$ & 31 & 25.83 \\
\hline & & Mean=23.54 SD=3.53 \\
\hline
\end{tabular}


Table. 2 Practice-wise adoption of blackgram growers about recommended cultivation practices

$(\mathrm{n}=120)$

\begin{tabular}{|c|c|c|c|c|c|c|c|}
\hline \multirow{3}{*}{$\begin{array}{l}\text { SI. } \\
\text { No. }\end{array}$} & \multirow[t]{3}{*}{ Components } & \multicolumn{6}{|c|}{ Adoption level } \\
\hline & & \multicolumn{2}{|c|}{ Full adoption } & \multicolumn{2}{|c|}{ Partial adoption } & \multicolumn{2}{|c|}{ No adoption } \\
\hline & & $\mathbf{F}$ & $\%$ & $\mathbf{F}$ & $\%$ & $\mathbf{F}$ & $\%$ \\
\hline $\mathbf{I}$ & Cultivation practices & & & & & & \\
\hline 1 & Varieties (DU-1 and TAU-1) & 115 & 95.83 & 0 & 0.00 & 5 & 4.17 \\
\hline 2 & Sowing time (May to June) & 120 & 100.00 & 0 & 0.00 & 0 & 0.00 \\
\hline 3 & Seed rate $(6-6.4 \mathrm{~kg} / \mathrm{acre})$ & 83 & 69.17 & 37 & 30.83 & 0 & 0.00 \\
\hline 4 & Seed treatment (Rhizobium) & 32 & 26.67 & 0 & 0.00 & 88 & 73.33 \\
\hline 5 & Seed treatment dosage $(200 \mathrm{~g} / \mathrm{acre})$ & 21 & 17.50 & 11 & 9.17 & 88 & 73.33 \\
\hline 6 & Spacing $(30 \times 10 \mathrm{~cm})$ & 73 & 60.83 & 47 & 39.17 & 0 & 0.00 \\
\hline 7 & Intercropping (Blackgram + Redgram, Blackgram + bajra, Blackgram + jawar) & 82 & 68.33 & 0 & 0.00 & 38 & 31.67 \\
\hline II & Fertilizers & & & & & & \\
\hline 1 & FYM (2 tonnes/acre) & 8 & 6.67 & 24 & 20.00 & 88 & 73.33 \\
\hline 2 & Time of application of FYM (2-3 Week before sowing) & 25 & 20.83 & 7 & 5.83 & 88 & 73.33 \\
\hline 3 & Chemical fertilizer (NPK 10:20:0 kg/acre) & 53 & 44.17 & 63 & 52.50 & 4 & 3.33 \\
\hline 4 & Time of application of chemical fertilizers (Basal dose) & 116 & 96.67 & 0 & 0.00 & 4 & 3.33 \\
\hline III & Weed management and intercultural operation & & & & & & \\
\hline 1 & Intercultivation (2 times - Within 40 DAS) & 69 & 57.50 & 51 & 42.50 & 0 & 0.00 \\
\hline 2 & Hand weeding (2 times) & 113 & 94.17 & 0 & 0.00 & 7 & 5.83 \\
\hline 3 & Herbicide application (Pre emergence- Pendamithelin, Fluchoralin and Allachlore) & 7 & 5.83 & 0 & 0.00 & 113 & 94.17 \\
\hline 4 & Time of application of herbicide (before and after sowing) & 7 & 5.83 & 0 & 0.00 & 113 & 94.17 \\
\hline IV & Plant protection measures & & & & & & \\
\hline 1 & Insect pest management & & & & & & \\
\hline $\mathbf{a}$ & $\begin{array}{l}\text { Agromicide fly (Dimethoate @ } 1.7 \text { ml/l, Phosphomidan @0.5ml/1, Imidachloprid @ } \\
0.3 \mathrm{ml} / \mathrm{l})\end{array}$ & 16 & 13.33 & 76 & 63.33 & 28 & 23.33 \\
\hline $\mathbf{b}$ & Aphids (Dimethoate @ 1.7 ml/l) & 21 & 17.50 & 76 & 63.33 & 23 & 19.17 \\
\hline $\mathbf{c}$ & Thrips (Monocrotophos@ 1 ml/l or Dimethoate @1.7ml/l) & 34 & 28.33 & 61 & 50.83 & 25 & 20.83 \\
\hline $\mathbf{d}$ & Pod borer (Methyl parathion@ @ 1 ml/l) & 13 & 10.83 & 88 & 73.33 & 19 & 15.33 \\
\hline 2 & Disease management & & & & & & \\
\hline $\mathbf{a}$ & Leaf spot (Mancozeb @ 2g/l or COC @ 3 g/l) & 8 & 6.67 & 17 & 14.17 & 95 & 79.17 \\
\hline $\mathbf{b}$ & Powdery mildew (Sulphur (WP) @ 3g/l or Carbondenzim @ 1g/l) & 19 & 15.83 & 59 & 49.17 & 42 & 35.00 \\
\hline $\bar{c}$ & Mosaic (Dimethoate@1.7ml/1 or Phosphomidan@0.5ml/l) & 8 & 6.67 & 19 & 15.83 & 93 & 77.50 \\
\hline
\end{tabular}


Cent per cent of the respondents fully adopted recommended sowing time for their region followed by variety $(95.83 \%)$. Whereas, nearly three fourth $(73.33 \%)$ of respondents not adopted seed treatment and dosage. However, majority $(69.17 \%)$ of respondents fully adopted seed rate followed by intercropping (68.33\%), spacing (60.83\%), seed treatment with Rhizobium $(26.67 \%)$ and seed treatment dosage $(17.50 \%)$. The reasons for adoption of these practices as recommended are the simplicity and low cost of the practices which can be practiced by making use of mere knowledge and their own resources without reliance on any external agency. Further, farmers as a result of their farming experience have themselves realized the usefulness of these practices. Regarding fertilizer, an equal per cent $(73.33 \%)$ of respondents not adopted FYM and time of application. Whereas only 20.00 per cent of respondents fully adopted FYM and followed time of application. The possible reason might be that high cost and non-availability of the FYM. Large majority (96.97 \%) of respondents fully adopted timely application of chemical fertilizer. However, more than half $(52.50 \%)$ of respondents partially adopted chemical fertilizer. Whereas 44.17 per cent of respondents had fully adopted chemical fertilizer. This might be due to less knowledge about quantity of chemical fertilizer. With regard to weed management and intercultural operations, 57.50 per cent of respondents adopted intercultivation. With regard to hand weeding, 94.17 per cent of respondents carried weeding during crop period. However, 94.17 per cent of respondents not adopted herbicides. This may be due to lack of knowledge about herbicide use and high cost. With respect to insect pest management, majority $(73.33 \%)$ of respondents partially adopted the chemical measures for pod borer followed by an equal per cent $(63.33 \%)$ of respondents followed it partially for the pest like agromicide fly and aphid and 50.83 per cent of respondents partially adapted management measures for thrips. With respect to disease management, majority $(79.17 \%)$ of the respondents not adopted the recommended management measures for leaf spot followed by mosaic $(77.50 \%)$ and powdery mildew $(35.00 \%)$. However, 49.17 per cent of respondents partially adopted management measures for powdery mildew. The reason might be low level education and lack of knowledge about the management of pest and diseases. The findings of the present study are in consonance with the results of Vedamurthy (2002), Raghavendra (2004) Upma et al., (2010), Dwivedi et al., (2011) and Vashishtha et al., (2011).

Adoption is a mental process. In the modern era new things are being invented by agricultural scientists but all the innovations are not being adopted by many of the members of social system. Adoption of an innovation depends on many factors viz., awareness and knowledge of adopters, innovativeness, characteristics of an innovations etc. It was concluded from the study that majority $(45.00 \%)$ of respondents had medium level adoption category followed by 29.17 per cent and 25.83 per cent of the respondents in low and high level adoption categories, respectively. Finding of the study indicates that, majority of the farmers had high school level education, medium land holding, medium level achievement motivation, medium innovativeness and medium level management orientation. Hence, all these factors might have influenced them to fall under medium adoption category. Further, as the land holding and income increases naturally and they prove towards economical returns. Good education level and farming experience might have increased their knowledge level and hence fell in medium adoption category so as to gain more income. Therefore, for enhancing the production and 
productivity of blackgram crop, strategy should be made for getting the more recommended technology adopted by the farmers. The Extension programme may effective in changing attitude skill and knowledge of recent technology for high yielding varieties, good disease and pest management of blackgram including their adoption.

\section{References}

Angadi, S. C., 1999. A study on knowledge, adoption and marketing pattern of pomegranate growers in Bagalkot district. M. Sc. (Agri.) Thesis, Univ. Agric. Sci., Dharwad (India).

Anonymous, 2012. Area, production and productivity of major pulses, Ministry of Agriculture, Govt of India., pp: 183 199

Anonymous, 2013. Status paper on pulses, GOI, (Department of agriculture and cooperation) Directorate of pulses development, Pp: 3-8.

Ashish Kumar, Rathod, M. K. and Kalantri, L. B., 2012. Behaviour of farmers in adoption of recommended technology of soybean. Indian Res. J. Ext. Edu., 2: 223-227.

Avinash Khare, Wakle, P. K., Shambharkar, Y. B. and Patil, J., 2013. Correlates of adoption and constraints faced by the gram farmers in adoption of improved cultivation practices. Indian J. Res., 2 (10): 8-10.

Bhagwan Singh and Chauhan, T. R., 2010. Adoption of mungbean production technology in arid zone of Rajashtan. Indian Res. J. Ext. Edu., 10 (2): 73-77.

Das, J. K., Gosawmi, K. K., Mazumder, G. and Bhattacharyya, D., 2008. Diffusion and adoption of mustard production technology. J. Interacad., 12 (4): 563 567.

Dwivedi, A. P., Singh, S. R. K., Mishra, A.
Singh. R. P. and Mamta Singh, 2011. Adoption of improved production technology of pigeonpea. J. Com. Mob. \& Sus. Dev., 6 (2): 150-154.

Jadhav, K. and Aski. S. G., 2014. Extent of adoption of redgram production technologies by the trained and untrained farmers. Int. J. Pl. Sci., 9 (2): 431-434

Kanavi, V. P., 2000. A study on the knowledge and adoption behaviour of sugarcane growers in Belgaum district of Karnataka. M. Sc. (Agri.) Thesis, Univ. Agric. Sci., Dharwad (India).

Karpagam, C., 2000. A study on knowledge and adoption behaviour of turmeric growers in Erode district of Tamil Nadu state. M. Sc. (Agri.) Thesis, Univ. Agric. Sci., Dharwad (India).

Kumbhare, N. V. and Singh, 2011. Adoption of behaviour and constraints in wheat and paddy production technologies. Indian Res. J. Ext. Edu., 11 (3): 41-44.

Lokesh Sirohiya, D. K., Singh, S.K. and Agarwal, 2012. Impact of training on adoption of chickpea (Cicera arietinum) production technology. Indian J. Ext. Edu., 48 (3 \& 4): 87-89.

Maraddi, G. N. and Verma, N. S., 2003. Adoption of cotton production technologies by the farmers of Malaprabha command area of Karnataka, Karnataka J. Agric. Sci., 16 (1): 137-140.

Muhammad, T. K., 2000. Adoption of recommended practices of soybean cultivation by farmers. Int. J. Agri. Biol., 2 (4): 336-337.

Nanchhu Ram Meena, Sisodia, S. S., Dangi, K. L., Jain, H. K. and Chakravarti, D., 2011. Adoption of improved cluster bean cultivation practices by the farmers. Raj. J. Extn. Edu., 19: 101-103.

Raghavendra, M. R., 2004. Knowledge and adoption of post-harvest technologies by Redgram cultivators in Gulbarga 
district of Karnataka. M. Sc. (Agri.) Thesis, Univ. Agric. Sci., Dharwad (India).

Singh, B., Singh, Y. K. and Tushar, K. P., 2014. Extent of adoption of recommended practices of pulses through FLD. J. Agric. Vet. Sci., 7 (12): 71-72.

Singh, P., Lakhera, J. P. and Subhash Chandra, 2012a. Knowledge and adoption of mothbean production technology in Western zone of Rajasthan. Raj. J. Extn. Edu, 20: 35-38.

Srivsatava, J. P., Dipak Kumar, B. and Jitendra Singh, 2013. Adoption behaviour of pigeonpea growers in Allahabad district of Uttar Pradesh. Indian J. Ext. Edu., 49 (1 \& 2): 110111.

Tidke, G. R., Rathod, M. K. and Mandve, R. P., 2012. Knowledge and adoption of farmers about the management of pod borer complex in pigeon pea. Int. $J$. Extn. Edu, 8: 76-78.

Vashishtha, U., Sharma, F. L. and Sisodia, S. S., 2011. Adoption of pigeonpea production technology in Udaipur district of Rajasthan. J. Pro. Agric., 2 (3): 88-90.

\section{How to cite this article:}

Ashokkumar, B., J. Tulasiram, G.N. Maraddi and Basavaraj Hulagur. 2018. A Study on Adoption Level of Recommended Cultivation Practices of Blackgram Growers in North Eastern Karnataka, India. Int.J.Curr.Microbiol.App.Sci. 7(02): 567-574.

doi: https://doi.org/10.20546/ijcmas.2018.702.072 